\title{
ANALISIS KRITIS TERHADAP EKSISTENSI BAHASA DAERAH MAKASSAR SEBAGAI MUATAN LOKAL DI SEKOLAH DASAR KOTA MAKASSAR PASCA IMPLEMENTASI KURIKULUM 2013
}

\author{
Sitti Rabiah ${ }^{2}$ \\ Fakultas Sastra \\ Universitas Muslim Indonesia, Makassar
}

\begin{abstract}
Abstrak
Implementasi Kurikulum 2013 menuai pro dan kontra di tengah-tengah masyarakat. Akhirnya muncul anggapan bahwa kegagalan penyelenggaraan pendidikan di Indonesia disebabkan oleh kesalahan rancangan kurikulum. Hal tersebut yang menjelaskan mengapa perubahan kurikulum terjadi sejak 1968-2006 telah terjadi sebanyak tujuh kali. Hingga akhirnya disusunlah Kurikulum 2013 untuk menyempurnakan kurikulum tahun-tahun sebelumnya. Makalah ini akan menjelaskan spesifik terhadap dampak yang ditimbulkan atas implementasi kurikulum 2013 dalam mata pelajaran bahasa Makassar sebagai muatan lokal di Sekolah Dasar Kota Makassar. Temuan dari penelitian ini adalah teridentifikasinya tiga hal yang menjadi ancaman bagi eksistensi bahasa Daerah/Makassar dalam institusi pendidikan formal, khususnya di Sekolah Dasar: (1) tidak adanya kompetensi dasar untuk mata pelajaran muatan lokal (bahasa Daerah), (2) terintegrasinya bahasa Daerah dalam beberapa Kompetensi Dasar mata pelajaran, dan (3) kontradiksi kurikulum 2013 dengan upaya pemertahanan bahasa Daerah.
\end{abstract}

Kata Kunci: Kurikulum 2013, Bahasa Makassar, Muatan Lokal, Sekolah Dasar, Kota Makassar

Abstract

Implementation of Curriculum 2013 some pros and cons in the midst of society. Finally emerging notion that the failure of education in Indonesia are caused by faulty design of the curriculum. This explains why the curriculum changes have occurred since 1968-2006 has occurred seven times. Until finally drafted curriculum in 2013 to enhance the curriculum in previous years. This paper will describe the specific impact of the implementation of the curriculum in 2013 in Makassarese language subjects as local content in Makassar City Elementary School. The findings of this paper is the identification of three things that constitute a threat to the existence of regional language /Makassarese in formal educational institutions, especially in Elementary School: (1) lack of basic competence for local content subjects (regional language), (2) the integration of regional language in some Basic Competence subjects, and (3) the contradiction between curriculum 2013 by the Regional language preservation efforts .

Keywords: Curriculum 2013, Makassarese Language, Local Content, Elementary School, Makassar City

\footnotetext{
1 Makalah telah dipresentasikan dalam Musyawarah dan Seminar Nasional Asosiasi Jurusan/ Program Studi Pendidikan Bahasa dan Sastra Indonesia (AJPBSI) yang diselenggarakan oleh Program Studi Pendidikan Bahasa dan Sastra Indonesia, FKIP, Universitas Sebelas Maret pada 24-25 Oktober 2014 di Surakarta, Indonesia.

2 (iD https:// orcid.org/ 0000-0002-1690-0025. Kontak penulis: sitti.rabiah@umi.ac.id / sittirabiah25@gmail.com
} 


\section{A. Pendahuluan}

Implementasi Kurikulum 2013 menuai pro dan kontra di berbagai kalangan. Tidak terkecuali di kalangan pemerhati pendidikan. Sehingga perdebatan seputar perubahan kurikulum menjadi tema utama yang menarik untuk dikaji secara ilmiah dan akademik. Secara ilmiah, kurikulum tidak hanya ditinjau dari aspek teoretis melainkan harus ditinjau dari aspek aktualisasinya dalam mengembangkan pendidikan demi untuk memanusiakan manusia dan mencerdaskan kehidupan bangsa, sebagaimana amanat pembukaan konstitusi Republik Indonesia. Secara akademik, dinamika pembahasan kurikulum menjadi studi yang terjadi secara terus menerus dan bersifat keberlanjutan dan penyempurnaan (sustainability and improvement). Hal ini disebabkan dinamika yang terjadi dalam dunia pendidikan turut dipengaruhi tren pendidikan di kancah global dan kompleksitas kehidupan masyarakat dunia ( global village).

Dalam perkembangan penyelenggaraan pendidikan di Indonesia, tercatat sebanyak tujuh kali penyelenggaraan kurikulum pendidikan dasar dan menengah yang dibarengi dengan perubahan strategi belajar mengajar. Kurikulum pertama dirancang pada tahun 1968 yang menitikberatkan pada pentingnya pembinaan moral, budi pekerti, agama, kecerdasan dan keterampilan, serta fisik yang kuat dan sehat. Kemudian disempurnakan lagi pada Kurikulum 1975 yang mengembangkan pada tiga aspek yakni kognisi, afektif, dan psikomotor, lalu dirancang kembali kurikulum 1984 sebagai penyempurnaan kurikulum sebelumnya yang menekankan pada Cara Belajar Siswa Aktif (CBSA).

Setelah dijalankan selama kurang lebih sepuluh tahun, implementasi kurikulum 1984 dianggap terlalu membebani guru dan murid mengingat jumlah materi yang terlalu banyak dibandingkan dengan ketersediaan waktu. Dengan demikian, maka lahirlah kurikulum 1994 sebagai hasil penyederhanaan kurikulum 1984. Namun demikian, kurikulum 1994 dinilai belum dapat memberikan standar yang baik untuk pendidikan di Indonesia. Hal ini ditunjukkan dari terpuruknya mutu pendidikan hingga berada pada level ke-12 dari 12 negara di Asia pada saat itu.

Dalam rangka membangkitkan posisi Indonesia dari keterpurukan ke arah yang lebih baik, maka disusunlah Kurikulum 2004 yang dikenal dengan 'Kurikulum Berbasis Kompetensi' (KBK). Hanya berselang 2 tahun kemudian KBK dipandang perlu untuk disempurnakan, maka lahirlah Kurikulum Tingkat Satuan Pendidikan (KTSP) atau Kurikulum 2006 yang berorientasi pada pengerahan upaya untuk menggali dan memberdayakan nilai-nilai lokal dengan prinsip berpikir global dan bertindak lokal (think globally and act locally).

Secara umum KTSP dirancang untuk memandirikan dan memberdayakan satuan pendidikan melalui pemberian kewenangan (otonomi) kepada lembaga pendidikan dan mendorong satua pendidikan untuk melakukan pengambilan keputusan secara partisipatif dalam pengembangan kurikulum. Namun demikian, setelah berjalan selama 6 tahun, implementasi KTSP dipandang belum dapat berjalan sesuai yang dicita-citakan yakni membentuk generasi yang berkarakter sesuai dengan nilai-nilai dan budaya bangsa. Maka dari itu dipandang perlu untuk disempurnakan dalam Kurikulum 2013 
guna menyukseskan tujuan pendidikan Indonesia untuk mencerdaskan kehidupan bangsa dan berbasis kepada nilai-nilai luhur budaya bangsa.

Anggapan bahwa kegagalan penyelenggaraan pendidikan di Indonesia yang disebabkan oleh kesalahan rancangan kurikulum, sepertinya merupakan penjelasan atas dinamika perubahan kurikulum sejak 1968-2006, yang berlanjut disusunnya kurikulum 2013. Anggapan seperti itu telah mengabaikan faktor lain yang ikut mempengaruhi terjadinya kegagalan tersebut. Beberapa faktor yang dimaksud adalah kompetensi guru dalam melaksanakan kurikulum, ketidaktersediaan sarana dan prasarana sekolah, kurangnya keterlibatan stakeholder, tidak terciptanya kerjasama yang baik antara perguruan tinggi sebagai pencetak tenaga guru, pemerintah, dan sekolah, sistem evaluasi dan standarisasi nasional dan daerah yang tidak akurat, dan ketidakjelasan arah serta model pendidikan yang diselenggarakan. Dengan demikian, pandangan pro dan kontra seputar perubahan kurikulum tersebut tak dapat dielakkan walaupun pemerintah berkomitmen untuk menerapkan Kurikulum 2013 pada bulan Juli 2013.

Sedangkan pandangan yang pro pada perubahan kurikulum KTSP menuju Kurikulum 2013 didasari atas kajian mendalam dengan melihat berbagai kesenjangan yang terjadi yang secara keseluruhan ditinjau dari enam komponen utama, yakni (1) kompetensi lulusan, (2) materi pembelajaran, (3) proses pembelajaran, (4) penilaian, (5) pendidik dan tenaga pendidik, dan (6) pengelolaan kurikulum yang masih jauh dari kondisi ideal. Oleh karena itu muncullah dugaan bahwa KTSP (Kurikulum 2006) terlalu menitikberatkan pada aspek kognitif yang menyebabkan beban siswa menjadi terlalu berat dan kurang bermuatan nilai-nilai karakter dan budaya bangsa sehingga menimbulkan dampak negatif bagi pelajar yang mengemuka beberapa tahun terakhir ini.

Dalam makalah ini, penulis ingin menyoroti secara spesifik dampak yang ditimbulkan atas implementasi kurikulum 2013 terhadap mata pelajaran bahasa Makassar sebagai muatan lokal di Sekolah Dasar Kota Makassar. Salah satu permasalahan yang muncul adalah mata pelajaran ini digolongkan ke dalam muatan lokal yang tidak secara spesifik disebutkan kewajiban penggunaannya dalam Kurikulum 2013. Hal ini mendorong penulis untuk memaparkan analisis kritis terhadap terancamnya pengajaran bahasa Daerah dalam institusi pendidikan formal sebagai masukan bagi pemerintah untuk menegaskan keberadaan bahasa Daerah sebagai muatan lokal dalam penyelenggaraan pendidikan di institusi formal (sekolah). Lebih lanjut, penulis akan memfokuskan pembahasan pada jenjang pendidikan sekolah dasar yang merupakan pendidikan tahap awal dan memberikan pengaruh signifikan terhadap perkembangan mental dan intelektual generasi muda Indonesia.

\section{B. Kedudukan dan Fungsi Bahasa Makassar}

Bagian ini ditujukan untuk memberikan pemahaman tentang kedudukan dan fungsi bahasa Makassar sehingga dapat diketahui urgensi pengajarannya kepada siswa sekolah dasar. Sebagaimana diketahui bahwa kedudukan bahasa Makassar sejajar dengan bahasa-bahasa lainnya di daerah yakni sebagai bahasa Daerah. Kedudukan ini 
berdasarkan kenyataan bahwa bahasa Makassar menjadi bahasa pengantar dan penghubung antar penutur bahasa Makassar dan sekaligus sebagai pendukung kebudayaan masyarakat Sulawesi Selatan umumnya dan masyarakat kota Makassar khususnya.

Hal ini terlihat pada penggambaran mengenai masyarakat Makassar, yang dalam tradisi sikap, serta bahasa merupakan hal yang membedakannya dengan kesatuan masyarakat lainnya. Walaupun dalam banyak tulisan, kelompok masyarakat Makassar ini disebut suku Makassar. Meskipun demikian, secara luas di masyarakat, kedua suku besar yang bermukim di Sulawesi Selatan, suku Bugis dan suku Makassar, lebih lazim disatukan menjadi suku Bugis-Makassar. Dalam kenyataannya, memang tidak banyak perbedaan, yang menonjol hanyalah pada bahasa yang digunakannya. Oleh karena itu, sebutan tentang masyarakat Makassar lebih sering dikaitkan dengan penutur bahasa Makassar.

Menurut Alwi dan Sugono (2003:40), kedudukan bahasa daerah harus dilihat dua sudut pandang: (1) bahasa daerah sebagai sarana komunikasi bagi para penutur yang berasal dari kelompok etnik yang sama, dan (2) bahasa daerah dalam kaitannya dengan bahasa Indonesia. Dilihat dari kedudukan yang disebutkan pertama, bahasa daerah berfungsi sebagai: (1) lambang kebanggaan daerah, (2) lambang identitas daerah, (3) alat penghubung di dalam keluarga dan masyarakat daerah, (4) sarana pendukung budaya daerah dan bahasa Indonesia, dan (5) pendukung sastra daerah dan sastra Indonesia.

Kedudukan bahasa daerah, termasuk didalamnya bahasa Makassar seperti yang telah dipaparkan di atas sejalan dengan tujuan yang dicita-citakan dalam penyusunan kurikulum yakni menjadikan generasi muda Indonesia menjadi insan yang cerdas serta menjadi generasi yang berkarakter sesuai dengan nilai-nilai dan budaya bangsa. Pengembangan pembelajaran bahasa Daerah seharusnya menjadi jalan bagi berbagai pihak termasuk pengambil keputusan (stakeholder) untuk menginternalisasikan nilainilai kearifan lokal salah satunya melalui mata pelajaran ini. Maka keberadaan bahasa Makassar dan bahasa-bahasa Daerah lainnya seharusnya bukan menjadi beban bagi siswa, melainkan menjadi sarana untuk mendekatkan diri kepada kebudayaan daerah yang memiliki ciri khas yang berbeda-beda di setiap daerah.

\section{Mata Pelajaran Bahasa Makassar sebagai Muatan Lokal dalam Kurikulum 2013}

Berdasarkan dokumen Kurikulum 2013 yang dirilis oleh Kementerian Pendidikan dan Kebudayaan (Kemdikbud) RI tentang Kompetensi Dasar terdapat empat bab, disertai lampiran-lampiran sesuai dengan kompetensi inti dan dasar yang dimiliki oleh setiap mata pelajaran. Empat bab tersebut terdiri atas: (1) Struktur Kurikulum, (2) Organisasi Kompetensi Dasar dalam Mata Pelajaran, (3) Kompetensi Inti dan Kompetensi Dasar, dan (4) Pembelajaran Tematik. Dalam pemaparan pada bagian ini, penulis tidak akan menyoroti seluruh bab dan mata pelajaran, melainkan hanya berfokus 
pada pembahasan yang memiliki hubungan dengan pembelajaran bahasa Daerah/Makassar.

\section{Struktur Kurikulum}

Secara umum, struktur kurikulum menggambarkan konseptualisasi konten kurikulum dalam bentuk mata pelajaran, posisi konten/mata pelajaran dalam kurikulum, dostribusi konten/mata pelajaran dalam semester atau tahun, beban belajar untuk mata pelajaran dan beban belajar per minggu untuk setiap siswa. Struktur kurikulum adalah juga merupakan aplikasi konsep pengorganisasian konten dalam sistem belajar dan pengorganisasian beban belajar dalam sistem pembelajaran. Pengorganisasian konten dalam sistem belajar yang digunakan untuk kurikulum yang akan datang adalah sistem semester sedangkan pengorganisasian beban belajar dalam sistem pembelajaran berdasarkan jam pelajaran per semester. (Kemdikbud, 2013: 1)

Struktur kurikulum adalah juga gambaran mengenai penerapan prinsip kurikulum mengenai posisi seorang siswa dalam menyelesaikan pembelajaran di suatu satuan atau jenjang pendidikan. Dalam struktur kurikulum menggambarkan ide kurikulum mengenai posisi belajar seorang siswa yaitu apakah mereka harus menyelesaikan seluruh mata pelajaran yang tercantum dalam struktur ataukah kurikulum memberi kesempatan kepada siswa untuk menentukan berbagai pilihan. Struktur kurikulum terdiri atas sejumlah mata pelajaran, beban belajar, dan kalender pendidikan (Kemdikbud, 2013: 1). Selengkapnya struktur kurikulum tersebut dipaparkan di dalam tabel berikut:

\begin{tabular}{|c|c|c|c|c|c|c|c|}
\hline & \multirow{2}{*}{ MATA PELAJARAN } & \multicolumn{6}{|c|}{$\begin{array}{l}\text { ALOKASI WAKTU BELAJAR } \\
\text { PER MINGGU } \\
\end{array}$} \\
\hline & & $\mathbf{I}$ & II & III & IV & $\overline{\mathbf{V}}$ & VI \\
\hline \multicolumn{8}{|c|}{ Kelompok A } \\
\hline 1. & Pendidikan Agama dan Budi Pekerti & 4 & 4 & 4 & 4 & 4 & 4 \\
\hline 2. & Pendidikan Pancasila dan Kewarganegaraan & 5 & 6 & 6 & 4 & 4 & 4 \\
\hline 3. & Bahasa Indonesia & 8 & 8 & 10 & 7 & 7 & 7 \\
\hline 4. & Matematika & 5 & 6 & 6 & 6 & 6 & 6 \\
\hline 5. & Ilmu Pengetahuan Alam & - & - & - & 3 & 3 & 3 \\
\hline 6. & Ilmu Pengetahuan Sosial & - & - & - & 3 & 3 & 3 \\
\hline \multicolumn{8}{|c|}{ Kelompok B } \\
\hline 1. & Seni Budaya dan Prakarya (termasuk muatan lokal)* & 4 & 4 & 4 & 6 & 6 & 6 \\
\hline 2. & $\begin{array}{l}\text { Pendidikan Jasmani, Olah Raga dan Kesehatan (termasuk } \\
\text { muatan lokal) }\end{array}$ & 4 & 4 & 4 & 3 & 3 & 3 \\
\hline \multicolumn{2}{|r|}{ Jumlah Alokasi Waktu Per Minggu } & 30 & 32 & 34 & 36 & 36 & 36 \\
\hline
\end{tabular}

Keterangan: *Muatan lokal dapat memuat Bahasa Daerah

Dijelaskan lebih lanjut bahwa, kelompok A adalah mata pelajaran yang memberikan orientasi kompetensi lebih kepada aspek kognitif dan afektif sedangkan kelompok B adalah mata pelajaran yang lebih menekankan pada aspek afektif dan psikomotor. 


\section{Organisasi Kompetensi Dasar dalam Mata Pelajaran}

Khususnya untuk mata pelajaran bahasa Daerah yang tergolong ke dalam mata pelajaran muatan lokal, maka pengorganisasian mata pelajaran ini mengikuti pendekatan terintegrasi (integrated curriculum) yang dinilai efektif oleh Kemdikbud untuk mengurangi beban belajar siswa dan penyederhanaan (Kemdikbud, 2013: 4). Adapun pengaruhnya terhadap bahasa Daerah/Makassar yakni kompetensi dasar muatan lokal yang berkenaan dengan bahasa Daerah diintegrasikan ke dalam mata pelajaran Seni Budaya dan Prakarya.

\section{Kompetensi Inti dan Kompetensi Dasar}

Kompetensi Inti merupakan terjemahan atau operasionalisasi SKL dalam bentuk kualitas yang harus dimiliki mereka yang telah menyelesaikan pendidikan pada satuan pendidikan tertentu atau jenjang pendidikan tertentu, gambaran mengenai kompetensi utama yang dikelompokkan ke dalam aspek sikap, pengetahuan, dan keterampilan (afektif, kognitif, dan psikomotor) yang harus dipelajari peserta didik untuk suatu jenjang sekolah, kelas dan mata pelajaran. Kompetensi Inti harus menggambarkan kualitas yang seimbang antara pencapaian hard skills dan soft skills (Kemdikbud, 2013: 5-8). Selengkapnya kompetisi inti SD dipaparkan sebagai berikut:

\begin{tabular}{|c|c|}
\hline $\begin{array}{c}\text { KOMPETENSI INTI } \\
\text { KELAS I DAN KELAS II }\end{array}$ & $\begin{array}{l}\text { KOMPETENSI INTI } \\
\text { KELAS III }\end{array}$ \\
\hline $\begin{array}{l}\text { 1. Menerima dan menjalankan ajaran agama } \\
\text { yang dianutnya }\end{array}$ & $\begin{array}{l}\text { 1. Menerima dan menjalankan ajaran agama } \\
\text { yang dianutnya }\end{array}$ \\
\hline $\begin{array}{l}\text { 2. Memiliki perilaku jujur, disiplin, tanggung } \\
\text { jawab, santun, peduli, dan percaya diri } \\
\text { dalam berinteraksi dengan keluarga, } \\
\text { teman, dan guru }\end{array}$ & $\begin{array}{l}\text { Memiliki perilaku jujur, disiplin, } \\
\text { tanggung jawab, santun, peduli, dan } \\
\text { percaya diri dalam berinteraksi dengan } \\
\text { keluarga, teman, tetangga, dan guru. }\end{array}$ \\
\hline $\begin{array}{l}\text { 3. Memahami pengetahuan faktual dengan } \\
\text { cara mengamati [mendengar, melihat, } \\
\text { membaca] dan menanya berdasarkan rasa } \\
\text { ingin tahu tentang dirinya, makhluk } \\
\text { ciptaan Tuhan dan kegiatannya, dan } \\
\text { benda-benda yang dijumpainya di rumah } \\
\text { dan di sekolah }\end{array}$ & $\begin{array}{l}\text { 3. Memahami pengetahuan faktual dengan } \\
\text { cara mengamati [mendengar, melihat, } \\
\text { membaca] dan menanya berdasarkan rasa } \\
\text { ingin tahu tentang dirinya, makhluk } \\
\text { ciptaan Tuhan dan kegiatannya, dan } \\
\text { benda-benda yang dijumpainya di rumah, } \\
\text { sekolah, dan tempat bermain. }\end{array}$ \\
\hline $\begin{array}{l}\text { 4. Menyajikan pengetahuan faktual dalam } \\
\text { bahasa yang jelas dan logis, dalam karya } \\
\text { yang estetis, dalam gerakan yang } \\
\text { mencerminkan anak sehat, dan dalam } \\
\text { tindakan yang mencerminkan perilaku } \\
\text { anak beriman dan berakhlak mulia. }\end{array}$ & $\begin{array}{l}\text { 4. Menyajikan pengetahuan faktual dalam } \\
\text { bahasa yang jelas, logis, dan sistematis, } \\
\text { dalam karya yang estetis dalam gerakan } \\
\text { yang mencerminkan anak sehat, dan } \\
\text { dalam tindakan yang mencerminkan } \\
\text { perilaku anak beriman dan berakhlak } \\
\text { mulia. }\end{array}$ \\
\hline
\end{tabular}




\begin{tabular}{|c|c|}
\hline $\begin{array}{l}\text { KOMPETENSI INTI } \\
\text { KELAS IV }\end{array}$ & $\begin{array}{l}\text { KOMPETENSI INTI } \\
\text { KELAS V DAN VI }\end{array}$ \\
\hline $\begin{array}{l}\text { 1. Menerima, menghargai, dan } \\
\text { menjalankan ajaran agama yang } \\
\text { dianutnya. }\end{array}$ & $\begin{array}{l}\text { 1. Menerima, menghargai, dan menjalankan } \\
\text { ajaran agama yang dianutnya. }\end{array}$ \\
\hline $\begin{array}{l}\text { 2. Memiliki perilaku jujur, disiplin, } \\
\text { tanggung jawab, santun, peduli, dan } \\
\text { percaya diri dalam berinteraksi dengan } \\
\text { keluarga, teman, tetangga, dan guru. }\end{array}$ & $\begin{array}{l}\text { 2. Memiliki perilaku jujur, disiplin, } \\
\text { tanggung jawab, santun, peduli, percaya } \\
\text { diri, dan cinta tanah air dalam } \\
\text { berinteraksi dengan keluarga, teman, } \\
\text { tetangga, dan guru. }\end{array}$ \\
\hline $\begin{array}{l}\text { 3. Memahami pengetahuan faktual dengan } \\
\text { cara mengamati [mendengar, melihat, } \\
\text { membaca] dan menanya berdasarkan rasa } \\
\text { ingin tahu tentang dirinya, makhluk } \\
\text { ciptaan Tuhan dan kegiatannya, dan } \\
\text { benda-benda yang dijumpainya di rumah, } \\
\text { sekolah, dan tempat bermain. }\end{array}$ & $\begin{array}{l}\text { 3. Memahami pengetahuan faktual dan } \\
\text { konseptual dengan cara mengamati dan } \\
\text { mencoba [mendengar, melihat, } \\
\text { membaca] serta menanya berdasarkan } \\
\text { rasa ingin tahu secara kritis tentang } \\
\text { dirinya, makhluk ciptaan Tuhan dan } \\
\text { kegiatannya, dan benda-benda yang } \\
\text { dijumpainya di rumah, sekolah, dan } \\
\text { tempat bermain. }\end{array}$ \\
\hline $\begin{array}{l}\text { 4. Menyajikan pengetahuan faktual dalam } \\
\text { bahasa yang jelas, logis, dan sistematis, } \\
\text { dalam karya yang estetis dalam gerakan } \\
\text { yang mencerminkan anak sehat, dan } \\
\text { dalam tindakan yang mencerminkan } \\
\text { perilaku anak beriman dan berakhlak } \\
\text { mulia. }\end{array}$ & $\begin{array}{l}\text { Menyajikan pengetahuan faktual dan } \\
\text { konseptual dalam bahasa yang jelas, } \\
\text { logis, dan sistematis, dalam karya yang } \\
\text { estetis dalam gerakan yang } \\
\text { mencerminkan anak sehat, dan dalam } \\
\text { tindakan yang mencerminkan perilaku } \\
\text { anak beriman dan berakhlak mulia. }\end{array}$ \\
\hline
\end{tabular}

Kompetensi Dasar merupakan kompetensi setiap mata pelajaran untuk setiap kelas yang diturunkan dari Kompetensi Inti. Kompetensi Dasar adalah konten atau kompetensi yang terdiri atas sikap, pengetahuan, dan ketrampilan yang bersumber pada kompetensi inti yang harus dikuasai peserta didik. Kompetensi tersebut dikembangkan dengan memperhatikan karakteristik peserta didik, kemampuan awal, serta ciri dari suatu mata pelajaran. Mata pelajaran sebagai sumber dari konten untuk menguasai kompetensi bersifat terbuka dan tidak selalu diorganisasikan berdasarkan disiplin ilmu yang sangat berorientasi hanya pada filosofi esensialisme dan perenialisme. Mata pelajaran dapat dijadikan organisasi konten yang dikembangkan dari berbagai disiplin ilmu atau non disiplin ilmu yang diperbolehkan menurut filosofi rekonstruksi sosial, progresif atau pun humanisme. Karena filosofi yang dianut dalam kurikulum adalah eklektik seperti dikemukakan di bagian landasan filosofi maka nama mata pelajaran dan isi mata pelajaran untuk kurikulum yang akan dikembangkan tidak perlu terikat pada kaedah filosofi esensialisme dan perenialisme (Kemdikbud, 2013: 5-8). Selanjutnya Kompetensi Dasar diturunkan dari Kompetensi Inti untuk setiap mata pelajaran. Termasuk bahasa Daerah/Makassar sebagai muatan lokal yang dikelompokkan ke dalam mata pelajaran Kelompok B. 


\section{Pembelajaran Tematik Integratif}

Kurikulum 2013 untuk Sekolah Dasar menggunakan pendekatan pembelajaran tematik integratif dari kelas I sampai kelas VI. Pembelajaran tematik integratif merupakan pendekatan pembelajaran yang mengintegrasikan berbagai kompetensi dari berbagai mata pelajaran ke dalam berbagai tema. Pengintegrasian tersebut dilakukan dalam dua hal, yaitu integrasi sikap, keterampilan dan pengetahuan dalam proses pembelajaran dan integrasi berbagai konsep dasar yang berkaitan. Tema merajut makna berbagai konsep dasar sehingga peserta didik tidak belajar konsep dasar secara parsial. Dengan demikian pembelajarannya memberikan makna yang utuh kepada peserta didik seperti tercermin pada berbagai tema yang tersedia. (Kemdikbud, 2013: 9)

\section{Terancamnya Eksistensi Mata Pelajaran Bahasa Makassar di Sekolah Dasar}

\section{Tidak Adanya Kompetensi Dasar untuk Mata Pelajaran Muatan Lokal (Bahasa Daerah)}

Penulis tidak menemukan bagian yang mengatur kompetensi dasar muatan lokal (bahasa Daerah/Makassar) di dalam dokumen Kurikulum 2013 yang seharusnya tercantum di dalam mata pelajaran kelompok B yakni mata pelajaran Seni, Budaya, dan Prakarya maupun Pendidikan Jasmani, Olah Raga, dan Kesehatan. Tidak adanya kompetensi dasar untuk mata pelajaran muatan lokal semakin mengancam eksistensi bahasa Daerah dalam pengajarannya di sekolah dasar, termasuk di dalamnya bahasa Makassar.

Tidak hanya itu, ancaman terhadap eksistensinya sebenarnya sudah terjadi sejak masa pemberlakuan Kurikulum Tingkat Satuan Pendidikan (KTSP)/Kurikulum 2006. Hal ini ditunjukkan dalam disertasi Sitti Rabiah (2012) yang mengangkat tentang Model Bahan Ajar Bahasa Makassar sebagai Muatan Lokal.

Rabiah (2012: 200-201) mengungkapkan bahwa pencapaian belajar siswa dalam pembelajaran bahasa Makassar berada di titik rendah, karena jam pelajaran yang sangat minim yakni 1 jam pelajaran setiap minggunya. Sedangkan diperlukan setidaknya 2 jam pelajaran setiap minggunya untuk memberikan peluang untuk memberikan materi ajar lebih banyak kepada siswa guna menambah pengetahuan dan wawasan siswa.

Di samping itu, temuan Rabiah (2012: 200-201) dalam penelitiannya menyatakan bahwa dalam rangka meningkatkan efektivitas pembelajaran bahasa Makassar diperlukan rancangan silabus pembelajaran bahasa Makassar. Dengan adanya silabus ini, maka pembelajaran yang akan disampaikan lebih terarah dan berkesinambungan. Sehingga dalam proses pengajaran materi yang diajarkan dapat tersampaikan dengan baik dan sesuai dengan prioritas dan kebutuhan siswa.

Sedangkan, untuk meningkatkan efektivitas belajar-mengajar bahasa Makassar, maka diperlukan langkah-langkah konkrit yang dapat dilakukan seperti perancangan strategi pembelajaran yang bervariasi. Dengan strategi pembelajaran yang bervariasi, tentunya siswa tidak akan bosan dengan bahan ajar yang monoton. Hal ini dimaksudkan 
agar siswa dapat mengikuti pembelajaran dengan efektif, dan tanpa mengurangi konten yang ingin disampaikan.

Temuan-temuan di atas merupakan hasil penelitian atas bahan ajar bahasa Makassar yang berlandaskan pada Kurikulum Tingkat Satuan Pendidikan (KTSP)/Kurikulum 2006. Secara garis besar, Rabiah mengemukakan masalah yang terjadi antara lain: (1) kurangnya jam pelajaran yang dialokasikan untuk bahasa Makassar bagi siswa sekolah dasar, (2) diperlukannya acuan umum dari kurikulum bahasa Makassar agar dapat secara lebih spesifik disusun dalam silabus, dan (3) diperlukannya bahan ajar bahasa Makassar yang berbobot guna mengefektifkan proses belajar mengajar.

Maka dari itu, dikhawatirkan dengan tidak diaturnya hal-hal seperti kompetensi dasar untuk pengajaran bahasa Daerah/Makassar sebagai muatan lokal menjadikan implementasinya di sekolah dasar menjadi kehilangan landasan operasional dan posisinya menjadi opsional saja. Padahal tujuan yang dicita-citakan oleh kurikulum 2013 adalah membentuk karakter generasi muda melalui nilai-nilai kearifan lokal yang sebenarnya banyak diajarkan melalui pembelajaran bahasa Daerah.

Permasalahan yang timbul adalah apakah pembelajaran Seni, Budaya, dan Prakarya dapat berbagi dengan bahasa Daerah sebagai muatan lokal dengan pembagian waktu yang adil dan merata. Di samping itu, alokasi waktu yang diberikan untuk mata pelajaran kelompok B sangat minim dan terkadang pelaksanaannya tidak sesuai di lapangan (sekolah).

\section{Terintegrasinya Bahasa Daerah dalam Beberapa Kompetensi Dasar Mata Pelajaran}

Fakta yang menarik dari kurikulum 2013 adalah penerapan sistem pembelajaran tematik integratif, sehingga keberadaan bahasa Daerah menjadi terintegrasi ke dalam mata pelajaran lain. Sedangkan guru kelas belum tentu mampu untuk memberikan penjelasan memadai untuk mata pelajaran bahasa Daerah.

Berikut kutipan contoh kompetensi inti dan dasar beberapa mata pelajaran dari kurikulum 2013 untuk sekolah dasar yang didalamnya terdapat arahan untuk mengajarkan bahasa Daerah.

\begin{tabular}{|l|c|c|l|}
\hline \multicolumn{1}{|c|}{ Kompetensi Inti } & MP & Kls. & \multicolumn{1}{|c|}{ Kompetensi Dasar } \\
\hline $\begin{array}{l}\text { 1. Menerima dan menjalankan ajaran agama } \\
\text { yang dianutnya }\end{array}$ & BI & I & $\begin{array}{l}\text { 1.1 Menerima anugerah Tuhan Yang Maha } \\
\text { Esa berupa bahasa Indonesia yang dikenal } \\
\text { sebagai bahasa persatuan dan sarana belajar } \\
\text { di tengah keberagaman bahasa daerah }\end{array}$ \\
\hline $\begin{array}{l}\text { 2. Memiliki perilaku jujur, disiplin, } \\
\text { tanggung jawab, santun, peduli, dan percaya } \\
\text { diri dalam berinteraksi dengan keluarga, } \\
\text { teman, dan guru }\end{array}$ & BI & I & $\begin{array}{l}\text { 1.1 Memiliki kepedulian dan rasa ingin } \\
\text { tahu terhadap keberadaan wujud dan sifat } \\
\text { benda melalui pemanfaatan bahasa } \\
\text { Indonesia dan/atau bahasa daerah } \\
\ldots .\end{array}$ \\
\hline $\begin{array}{l}\text { 3. Memahami pengetahuan faktual dengan } \\
\text { cara mengamati [mendengar, melihat, } \\
\text { membaca] dan menanya berdasarkan rasa } \\
\text { ingin tahu tentang dirinya, makhluk ciptaan } \\
\text { Tuhan dan kegiatannya, dan benda-benda }\end{array}$ & SBP & I & $\begin{array}{l}\text { 3.5 Mengenal karya seni budaya benda } \\
\text { dan bahasa daerah setempat }\end{array}$ \\
\hline
\end{tabular}




\begin{tabular}{|l|l|l|l|}
\hline yang dijumpainya di rumah dan sekolah & & & \\
\hline $\begin{array}{l}\text { 4. Menyajikan pengetahuan faktual dalam } \\
\text { bahasa yang jelas dan logis, dalam karya } \\
\text { yang estetis dalam gerakan yang } \\
\begin{array}{l}\text { mencerminkan anak sehat, dan dalam } \\
\text { tindakan yang mencerminkan perilaku anak } \\
\text { beriman dan berakhlak mulia }\end{array}\end{array}$ & & & $\begin{array}{l}4.17 \text { Menceritakan karya seni budaya } \\
\text { benda dan bahasa daerah setempat }\end{array}$ \\
\hline
\end{tabular}

Ket: BI = Bahasa Indonesia; SBP = Seni, Budaya, dan Prakarya

Berdasarkan gambaran di atas, maka dikhawatirkan eksistensi pengajaran bahasa Makassar sebagai muatan lokal semakin hilang. Dikarenakan beberapa arahan dari Kompetensi Dasar di mata pelajaran bahasa Indonesia maupun Seni, Budaya, dan Prakarya, seperti yang contohnya ditampilkan di atas.

\section{Kontradiksi Kurikulum 2013 dengan Upaya Pemertahanan Bahasa Daerah}

Kontradiksi yang terjadi antara Kurikulum 2013 dengan kebijakan di tingkat provinsi/daerah juga merupakan ancaman bagi eksistensi bahasa Daerah sekolah. Pertentangan disebabkan ketidakjelasan status bahasa Daerah sebagai muatan lokal dengan upaya pemertahanan bahasa Daerah yang saat ini sedang digiatkan oleh Badan Pengembangan dan Pembinaan Bahasa (Badan Bahasa) dan pemerhati bahasa Daerah. Padahal diharapkan bahwa dengan upaya pemertahanan bahasa Daerah dapat menjadi penguat bagi kokohnya persatuan melalui bahasa Nasional/bahasa Indonesia.

Dalam hal ini, para pemerhati bahasa Daerah turut berpartisipasi dengan mendorong pemerintah daerah untuk melakukan tindakan terkait penyelamatan bahasa Daerah melalu pengesahan Peraturan Daerah tentang bahasa Daerah. Khususnya bahasa Makassar, pemerintah daerah telah diminta untuk mempercepat upaya penyelamatan bahasa-bahasa Daerah di Sulawesi Selatan melalui Kongres Bahasa-Bahasa Daerah Sulawesi Selatan II pada Oktober 2012 lalu telah didorong untuk mengesahkan Perda tentang Bahasa-Bahasa Daerah di Sulawesi Selatan, hal ini dimaksudkan agar seluruh pihak merasa terdorong untuk melestarikan bahasa daerah di wilayah yang menjadi tanggungjawabnya. Hal ini termasuk keberadaan bahasa Makassar yang digunakan di Kota Makassar dan daerah sekitarnya bersanding dengan bahsa Bugis.

Kontradiksi antara Kurikulum 2013 dengan semangat penyelamatan bahasa Daerah seharusnya tidak terjadi, karena kedua program tersebut mempunyai maksud yang mulia. Di satu sisi, Kurikulum 2013 merupakan penyempurnaan dari kurikulum sebelumnya dan tentunya memiliki ide dasar untuk memberikan yang terbaik bagi dunia pendidikan Indonesia. Sedangkan upaya pemertahanan bahasa Daerah merupakan upaya bersama dari berbagai kalangan, khususnya pemerhati bahasa Daerah untuk menyelamatkan bahasa-bahasa Daerah dari kepunahan. Seyogyanya kedua program tersebut dapat saling berkolaborasi dan saling menutupi kekurangan.

Ketiga pemaparan di atas yakni (1) tidak adanya kompetensi dasar untuk mata pelajaran muatan lokal (bahasa Daerah), (2) terintegrasinya bahasa Daerah dalam beberapa Kompetensi Dasar mata pelajaran, dan (3) kontradiksi kurikulum 2013 dengan upaya pemertahanan bahasa Daerah, merupakan bentuk kritik terhadap Kurikulum 
2013. Seyogyanya ketiga hal tersebut tidak menjadi ancaman bagi eksistensi mata pelajaran bahasa Makassar sebagai muatan lokal di sekolah dasar, melainkan sebagai upaya penyelamatan karena kondisi bahasa-bahasa Daerah di Indonesia saat ini sudah mendekati kepunahan karena kehilangan penuturnya.

\section{E. Penutup}

Kesimpulan

Penjelasan tentang kondisi mata pelajaran bahasa Makassar sebagai muatan lokal di sekolah dasar kota Makassar sebagaimana dipaparkan di atas dapat dipahami telah terancam dengan keberadaan Kurikulum 2013 yang justru tidak memberikan ruang gerak yang bebas bagi berkembangnya bahasa Daerah.

Penulis melakukan eksplanasi mulai dari kedudukan dan fungsi bahasa Makassar dilanjutkan dengan mata pelajaran bahasa Daerah sebagai muatan lokal dalam Kurikulum 2013 merupakan sarana untuk mengantar nalar pembaca terkait urgensi bahasa Makassar yang ditunjukkan oleh kedudukan dan fungsinya, sedangkan penjelasan tentang bahasa Makassar dalam Kurikulum 2013 dimaksudkan untuk memberikan gambaran umum terkait hubungan antara bahasa Makassar dan Kurikulum 2013.

Memasuki bagian terakhir, penulis menitikberatkan analisis kritis terhadap terancamnya eksistensi bahasa Daerah dalam institusi pendidikan formal (sekolah dasar). Tiga hal yang berhasil diidentifikasi penulis sebagai ancaman tersebut antara lain: (1) tidak adanya kompetensi dasar untuk mata pelajaran muatan lokal (bahasa Daerah), (2) terintegrasinya bahasa Daerah dalam beberapa Kompetensi Dasar mata pelajaran, dan (3) kontradiksi kurikulum 2013 dengan upaya pemertahanan bahasa Daerah.

Oleh karena itu, setelah teridentifikasinya ancaman tersebut. Kedepannya penulis mengharapkan ada upaya dari para pembuat kebijakan (stakeholder) untuk melakukan tindakan yang tepat untuk memberikan solusi terhadap implementasi Kurikulum 2013 dalam mata pelajaran bahasa Makassar sebagai muatan lokal di sekolah dasar kota Makassar.

\section{REFERENCES}

Alwi, Hasan dan Dendy Sugono. 2003. Politik Bahasa Nasional. Jakarta: Pusat Bahasa.

Brown, James Dean. 1995. The Elements of Language Curriculum: A Systematic Approach to Program Development. Boston: Heinle\&Heinle Publisher.

Dakir, H. 2004. Perencanaan dan Pengembangan Kurikulum. Yogyakarta: PT. Rineka Cipta.

Dubin, Fraida and Elite Olshtain. 1986. Course Design: Developing Programs and Materials for Language Teaching. Cambridge: Cambridge University Press. 
Halim, Amran. 1985. Seminar Penulisan Bahan Pengajaran Bahasa. Jakarta: Pusat Bahasa: Dikbud.

Hernawan, Asep Herry. 2006. Pengembangan Kurikulum dan Pembelajaran. Jakarta: Univ.Terbuka.

Kitao, Kenji dan S. Kathleen Kitao. Selecting and Developing Teaching/Learning Materials. (http://iteslj.org/Articles/Kitao-Materials.htm, diakses 20 Agustus 2013.

Kementerian Pendidikan dan Kebudayaan. 2011. Pembelajaran Kontekstual dalam Membangun Karakter Siswa. Jakarta: Kemdikbud RI.

Kementerian Pendididkan dan Kebudayaan. 2013. Kurikulum 2013. Jakarta: Kemdikbud RI.

Rabiah, Sitti. 2012a. "Pengembangan Bahan Ajar Bahasa Makassar sebagai Muatan Lokal untuk Sekolah Dasar di Kota Makassar" Disertasi, PPs Universitas Negeri Jakarta.

Rabiah, Sitti. 2012b. Revitalisasi Bahasa Daerah Makassar melalui Pengembangan Bahan Ajar Bahasa Makassar sebagai Muatan Lokal. Dipresentasikan dalam Kongres Internasional II Bahasa-Bahasa Daerah Sulawesi Selatan Tahun 2012. Makassar: Balai Bahasa Provinsi Sulawesi Selatan dan Provinsi Sulawesi Barat. doi: 10.31227/osf.io/bu64e

Rabiah, Sitti. 2013. Pengembangan Materi Ajar Bahasa Makassar berbasis Nilai-Nilai Karakter dan Kearifan Lokal di Sekolah Dasar Kota Makassar. Dipresentasikan dalam Konferensi Internasional Budaya Daerah. Sukoharjo: Ikatan Dosen Budaya Daerah Indonesia. doi: 10.31227/osf.io/s8uv5

Rabiah, Sitti. 2014. The Learning Model of Makassarese Language based on the Character Building Concept: Research and Development in Elementary School of Makassar City. Presented in $3^{\text {rd }}$ International Seminar on Languages nd Arts. Padang: Faculty of Languages and Arts Universitas Negeri Padang. doi: 10.31227/osf.io/en63f

Tomlinson, Brian. 1998. Materials Development in Language Teaching. Cambridge: Cambridge University Press.

Utomo, Erry dkk. 2000. Teknik Penulisan Buku Pelajaran Muatan Lokal Pendidikan Dasar (SD dan SLTP). Jakarta: Departemen Pendidikan Nasional. 